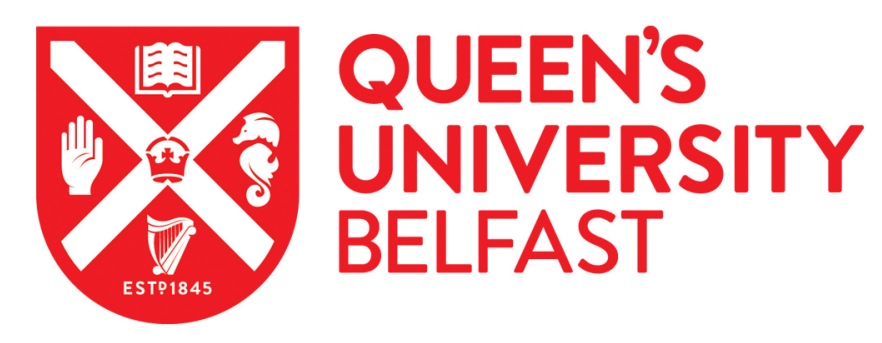

\title{
Being Irish
}

O'kelly, C. (2004). Being Irish. Government and Opposition, 39(3)(3), 504-520. https://doi.org/10.1111/j.14777053.2004.00132.x

\author{
Published in: \\ Government and Opposition
}

Document Version:

Early version, also known as pre-print

Queen's University Belfast - Research Portal:

Link to publication record in Queen's University Belfast Research Portal

\section{General rights}

Copyright for the publications made accessible via the Queen's University Belfast Research Portal is retained by the author(s) and / or other copyright owners and it is a condition of accessing these publications that users recognise and abide by the legal requirements associated with these rights.

Take down policy

The Research Portal is Queen's institutional repository that provides access to Queen's research output. Every effort has been made to ensure that content in the Research Portal does not infringe any person's rights, or applicable UK laws. If you discover content in the Research Portal that you believe breaches copyright or violates any law, please contact openaccess@qub.ac.uk. 
POLITICS OF IDENTITY: $\mathrm{V}^{1}$

Ciáran O'Kelly

\section{Being Irish $^{2}$}

A CERTAIN CONCEPTION OF CULTURAL IDENTITY WAS AT THE HEART OF the demand for Irish self-determination at the beginning of the twentieth century. It was crucial to independence from the United Kingdom in 1922, and has remained there since. This identity was rooted in a communitarian ideal that was, at times, set in opposition to individual welfare. In this article, I will explain how this idea of being Irish came about. I will then provide some specific examples of how - at the level of government action - the idea of being Irish competed with the liberal values upon which the state was founded.

The article is divided into three sections. After this introduction, the next section is devoted to setting out why cultural demands can have conservative consequences. I outline two disturbing characteristics of cultural demands - they tend to involve comprehensive conceptions of what it is to be a member of a group and are intolerant of dissent. Consequently, a state based on them risks letting its communitarian agenda trump individual rights. In the third section I provide some suggestions as to how the idea of being Irish developed. As I will argue, this idea had little to do with the prevailing realities of Irish society. In the final part I argue that the idea of being Irish has had profound implications for how Irish politics has been shaped. I explore how the debates over Europe, public morality and the structure of the relationship with Northern Ireland have been related to ideas of Being Irish. In each case, the two disturbing characteristics of cultural demands have all been too clearly in evidence.

\footnotetext{
1 'The Politics of Identity' is an on-going series edited by Richard Bellamy.

${ }^{2}$ My thanks go to Richard Bellamy, Alan Cromartie, Anne-Maree Farrell, Ron Peek and Niamh Nic Shuibhne for comments on an earlier draft of this paper. 


\section{CULTURAL POLITICS}

Encompassing groups lend value to people's lives. ${ }^{3}$ The political weight given to cultural demands reflects this fact while also being a function of the legacy of the imperialist adventures that European societies engaged in. Cultural politics is concerned with achieving some degree of equality between members of cultures as members of cultures. For example, language is often recognized as being more than an instrument for communication, but as something that is of deeper value to speakers. To lose a language, in short, causes harm.

Cultural politics is also a function of general rounds of bargaining and negotiation that take place within political institutions. Political demands are invariably aimed at achieving some form of autonomy for a group. The autonomy sought may not take the form of full independence. However, it will require either that the group in question is left alone to pursue special goals that are either not accessible or not interesting to the population at large, or that the larger community supports the group in pursuing these goals. Its pursuits are to lie outside the power and influence of the majority community even if the claimant seeks special funding. ${ }^{4}$

The specifically political content of cultural demands is of central importance to a discussion of Irish independence. As Avner de-Shalit writes, because cultural demands - for example leading to selfdetermination - are demands for action (rather than mere requests for toleration), they must be seen as political rather than cultural. ${ }^{5}$ Cultural demands are rooted in the seeking of advantage in the competition for resources. This makes them classically political - that is, they are rooted in institutional action. In this section, I will outline another level at which cultural demands are politically significant. Policy-makers have a responsibility to protect individuals from their communities and their community leaders as much as they have a duty to ensure the implementation of their rights. Given that, the

\footnotetext{
${ }^{3}$ On the defining characteristics of encompassing groups, see Avishai Margalit and Joseph Raz, 'National Self-Determination', in Joseph Raz, Ethics in the Public Domain, Oxford, Clarendon Press, 1994, pp. 128ff.

${ }^{4}$ See Jane Wright, 'Minority Groups, Autonomy, and Self-Determination', Oxford Journal of Legal Studies, 19: 4 (1999), p. $607 f$.

${ }^{5}$ Avner de-Shalit, 'National Self-Determination, Political, not Cultural', Political Studies, 44 (1996), p. 911.
} 
devolution of power in response to cultural demands is only a good if the consequences for the individuals affected are beneficial.

Demands rooted in cultures involve a systematic conception of membership and are intolerant of internal dissent. These distinctive characteristics emphasize the extent to which cultural demands should be subject to close political scrutiny. Cultural demands are potentially very harmful to members, both within the group and within society at large. A closer look at two distinct characteristics of cultural demands will help emphasize the risks inherent in such enterprises.

\section{Comprehensive Conceptions of Membership}

If a person wishes to gain subsidies for their industries, they may base their demand on appeals to equality, or to non-economic social values, or to ideas of desert. However, they need not base their demand on appeals to the special characteristics of claimants or constituents. Cultural claims, by contrast, do not focus solely on interests or principles. They also include comprehensive descriptions of characteristics that members are supposed to both share and value.

The autonomy sought by cultural claimants is justified on the grounds that the claimants' constituents cannot achieve an equal status with the majority community unless their demands are granted. If the demand takes this form, however, the claimant must describe the specific characteristics that are held back by the present institutional dispensation. So a marginal group may claim that their language is in danger unless they receive special treatment, say in the form of subsidized media. Alternatively, a group may claim that it requires autonomy in schooling if valuable cultural traits are to be passed on to the next generation.

Whatever the specific form that the demand takes, its cultural element means that the claimant, in addition to speaking of objective policies, refers to characteristics that are supposedly central to members of the group. As a result, the demand posits fundamental and deep aspects of the characters of all members, rather than psychologically shallow sets of interests. Moreover, the cultural demand rests on an assumed dependence between the individual's well-being and that of the group. To lose a cultural demand is more than merely disappointing or frustrating for the group. It is fatal. 


\section{Dissidence and Membership}

One issue that arises from the comprehensive descriptions that are included in cultural demands is that dissent is hard to take. If the demand is denied or disputed by purported members, then its credibility is undermined. To a greater extent than other sorts of claimants, people who make demands on behalf of cultural groups will be undermined by dissent. People who make interest-based demands will largely speak on behalf of constituencies that have voluntary memberships. A coincidence of interests can lead to an agreed agenda or, where methodological or policy differences emerge, people might easily opt out. In the case of cultural demands, however, membership is not presumed to be voluntary. Rather, members find themselves in a certain cultural environment. That is not to say that they are not happy to be as they are. The claim must be that people value their situations, even if they did not choose them. Dissidents upset the demand by challenging either the idea that culture is not chosen or that members are happy with the demand as articulated. Their very presence weakens the cause. ${ }^{6}$

The two special characteristics of cultural demands outlined above should make policy-makers very concerned. Even if justice dictates a generous reception for cultural demands, reasonably just states may find the demands of groups difficult to entertain. The formulation of cultural or group membership competes with the liberal attachment to the individual and to the individual's voluntary associations with groups. Liberalism, as Chaim Gans writes, 'can acknowledge the value of national groups only if it is based on fundamental interests of their individual members and if these interests are interests that could in principle be held by all human beings. ${ }^{7}$ The crucial question is not over whether we follow the communitarian claim that group membership is of central value to people, but over whether we allow this claim to trump liberal equality.

In the fourth part of this article, I will return to the two characteristics of cultural demands and provide examples of how they have

\footnotetext{
${ }^{6}$ To an extent, this paragraph tracks Margalit and Raz's description of the characteristics of encompassing groups. See Margalit and Raz, 'National SelfDetermination', op. cit., pp. $128 \mathrm{ff}$.

7 Chaim Gans, The Limits of Nationalism, Cambridge, Cambridge University Press, 2003, p. 169.
} 
been manifested in Ireland. A lack of toleration towards dissent shaped policy towards the Unionists in Northern Ireland, a group who were equally intolerant in return. The comprehensive conception of membership created tensions in the face of European integration and influenced public morality debates, for example over legislation prohibiting homosexual acts. It is not the formulation of the encompassing group - the idea of being Irish - in itself that mattered most, but both the manner in which the group was characterized and the political conclusions that have been drawn from the group's supposed character.

\section{BEING IRISH: CONSTRUCTING THE ENCOMPASSING GROUP}

In this section, I will provide a brief review of the idea of being Irish that dominated in the run-up to, and after independence. This idea of being Irish was rooted in a cultural claim and in a focus on specific characteristics that were held to define the Irish as an encompassing group. It is not my intention to provide a full historical analysis of the political and ideological trends of the time. Instead, the aim of the section is to highlight the level to which the demand for Irish independence was rooted in a comprehensive description of a homogenous cultural group. This idea led to the problems that I outline in the section on the consequences, below.

The Irish state is reasonably liberal. The constitution guaranteed conventional liberal freedoms and rights to individuals within the state's jurisdiction. There was no revolutionary intent in the secession. Although Ireland adopted republican institutions, rooted in a written constitution, these - in themselves - can hardly have been at the core of the independence movement. The secessionist agenda of the dominant element in post-1916 nationalism was justified on the idea that an Irish Ireland was seen as a good in itself. The question of whether independence provided a more advantageous position from which to pursue a justice-based agenda was of secondary importance. Instead of seeking to overthrow the statehood or prevailing socio-economic structures, the Irish rooted their demand for statehood in the idea that the Irish people deserved and needed to have control over their own affairs. As I said above, basing a state on such communitarian claims may impair the liberal aspects of constitutional democracy. The individual will have to compete with the 
perceived good of achieving a communitarian ideal, an ideal that may neither be achievable nor desirable in any case.

The Easter Rising in 1916 was the key moment in the contemporary conception of being Irish. The Rising largely involved a weeklong occupation by cultural nationalists of various parts of Dublin, notably the city's General Post Office. They proclaimed a republic but were suppressed by English troops. Thirteen leaders of the Rising, including Patrick Pearse and James Connolly, were executed, on the grounds that they were supposedly aiding the enemy at a time when the UK was at war. The Rising, when it happened, was very unpopular in Dublin and across the country. Constitutional nationalists, who had gained a commitment to Home Rule - essentially devolution - for after the First World War, had dominated Irish politics for some time. However, the mood in the country turned in the wake of the leaders' executions and the electoral weight of what was to become the Irish Free State (subsequently the Republic of Ireland) shifted towards the militant republican party, Sinn Féin.

The sense of being Irish that was promoted by Sinn Féin involved an idea of the Irish as an encompassing group who could not but be at odds with the English. They were essentially foreign to each other. This idea was not new and tapped into a long-standing sense of grievance, rooted both in a history of religious discrimination, in the social repercussions of the 1840 s famine and in an enormously inequitable position of land ownership.

The British government had, for a number of years, engaged in attempts to 'kill Home Rule with kindness.' A range of policies were aimed at tackling the underlying grievances, such as those surrounding land ownership, that provided the basis for support for Home Rule. As a result, a number of the justice-based grounds for demanding Home Rule had been addressed by the beginning of the First World War in 1914. Despite this, in the wake of the Easter Rising, the weight of Irish opinion shifted from general support for Home Rule to a demand for a clean break from the UK. In 1918, 93.3 per cent of people in what was to become independent Ireland voted for Sinn Féin, where, between 1885 and 1910, 96.3 per cent had voted in favour of parliamentary nationalist candidates. ${ }^{8}$ From 1918 to

\footnotetext{
${ }^{8}$ See table in John Coakley, 'The Foundations of Statehood', in John Coakley and Michael Gallagher, Politics in the Republic of Ireland, 3rd ddn, London, Routledge and the Political Studies Association of Ireland, 1999, p. 9.
} 
1921, a war of independence was fought and, in 1922, Ireland - with the exception of the north-eastern counties - seceded from the UK. ${ }^{9}$

The idea of being Irish that was articulated by the nationalists was rooted in the Celtic Revival. The Revival was an unashamedly romantic phenomenon, and one of the wave of 'volk' movements that arose throughout Europe in the mid- to late-nineteenth century. It was partly related to and a result of a new interest in culture and to the scholarly attention being paid to the recording and describing of the Irish language, music and history. Irish culture was in vogue. If we are to ask how Irish identity came about, it is partly through the influence of this romantic movement. One of the implications of the Revival, as with all cultural/identity movements, was that there was something truly Irish about people who lived Irish culture, and that there was something inauthentic about Irish people who lived without being embedded in the culture.

The Celtic Revival was largely an artistic movement. One of its most famous spokespersons, though neither the first nor the most convinced, was William Butler Yeats. His early poetry was inspired by the newly translated myths and legends of Ireland. Like John Synge, author of Playboy of the Western World, Yeats lauded the culture of the West of Ireland - conjuring up a frontier that, as with the American West, expressed something of the essence of the nation. The people of the West represented that ideal of Irishness, even if it diverged from reality. ${ }^{10}$ Nevertheless, according to the Yeatsian conception, the true Irish were the remnants of an unbroken line that provided a direct link to the ancient and pagan Ireland that was, most importantly, prior to England's political influence. Liberated sexually and socially, the people in the West, as portrayed by Yeats and others, lived lives joyously at odds with Victorian England's claustrophobic and repressed civilization. ${ }^{11}$

${ }^{9}$ Three key texts in Irish history are Joseph Lee, The Modernisation of Irish Society, Dublin, Gill and MacMillan, 1989; R. F. Foster, Modern Ireland 1600-1972, London, Penguin, 1989; F. S. L. Lyons, Ireland Since the Famine, London, Fontana, 1973.

${ }^{10}$ Edward Said, Culture and Imperialism, London, Vintage, 1994, p. 281. See also Luke Gibbons, Transformations in Irish Culture, Cork, Cork University Press, 1996.

11 W. B. Yeats. The Poems, London, Everyman, 1990; J. M. Synge, Collected Plays and Poems and The Aran Islands, London, Everyman, 1996; On Yeats and the Celtic Revival in general, see Luke Gibbons, Transformations in Irish Culture, op. cit.; Declan Kiberd, Inventing Ireland, London, Jonathon Cape, 1995; Marjorie Howes, Yeats's Nations, Cambridge, Cambridge University Press, 1996; A. Norman Jeffares, A New Commentary on the Poems of W. B. Yeats, London Macmillan, 1984. 
The Revival provided the basis for the nationalists' political movement. The switch to the demand for independence was not only aimed at ridding Ireland of English rule. It was also a move from largely justice-based to culturally-based demands for independence. The quest was now not just for political self-rule but also for cultural authenticity. As Michael Collins - one of the key figures in Sinn Féin during the War of Independence - put it,

It was not only by the British armed occupation that Ireland was subdued. It was by means of the destruction, after great effort, of our Gaelic civilisation. This destruction brought upon us the loss almost of nationality itself. For the last 100 years or more Ireland has been a nation in little more than in name. ${ }^{12}$

The 1916 Proclamation of the Republic - published at the beginning of the Easter Rising against British rule - declared that 'the Republic guarantees religious and civil liberty, equal rights and equal opportunities to all its citizens.' Alongside such ideas, the leaders of the Rising - most famously Patrick Pearse - believed that the independence of Ireland was not only, or perhaps not even primarily, a political project. Ridding the Irish of English government was not enough. They would have to be cleansed of their cultural rule.

The social and economic structures of the island were changing too. In the wake of the famine, a wave of large-scale migration had begun. The poorest people - those who spoke the Irish language and were in other ways most disconnected from British social structures - were either leaving for England, Scotland, Australia or America, or were migrating from the west of the island to Dublin. As the Celtic Revival was in full swing, the population of the country was collapsing, falling by half between the famine of the 1840s and independence in 1922. The Celtic Revival itself was largely a metropolitan phenomenon, celebrating a culture that was disappearing fast.

To summarize, Irish nationalism was rooted in a cultural claim that being Irish was incompatible with rule from England. However, the culture that was described by the Celtic Revival was a hybrid. It added Irish elements to wider European ideas of folk culture and to

${ }^{12}$ Michael Collins, The Path to Freedom - Articles and Speeches by Michael Collins, Cork, Mercier Press, 1968, p. 95. See also some comments of IRA fighter Ernie O'Malley, in Richard English, 'Green on Red - Two Case Studies in Early Twentieth Century Irish Republican Thought', in D. George Boyce et al. (eds), Political Thought in Ireland Since the Seventeenth Century, London, Routledge, 1993, p. 172. 
European methods of theatre and literature. As for the Irish language, its everyday use was restricted to the impoverished and increasingly depopulated west of the island. In a way, the cultural claim behind secession was made when the culture had already been lost.

\section{THE CONSEQUENCES OF IDENTITY POLITICS}

The nationalist movement that brought Ireland out of the UK was founded on ideas of being Irish that reflected the lives of Irish people less and less. The Irish encompassing group was not defined around everyday modes of behaviour such as language, or around traditions of law or social organization. Even the religious dimension cannot fully explain the route that the movement took. The perceived distinction between Irishness and Englishness did not fully come about as a result of recent tangible events. Rather, the cultural claim was a function both of European-style romantic nationalism and of the wider sense of grievance that arose from religious and other conflicts between the Irish periphery and the English metropolis. What the self-definition of the encompassing group did not involve was any urgent concept of cultural survival. It was sufficient to emphasize that difference necessitated an independent state. Again, the identity claim was not based on actual social structures, but on a compelling idea.

After independence, however, the cultural claim became one of the defining characteristics of the new state. This had concrete political consequences, some of which relate to the issues I raised above. In the next four subsections, I will highlight how specific aspects of the Irish identity - rooted in a comprehensive conception of membership and on a lack of toleration of dissidence - shaped Irish political life in the subsequent decades.

\section{Dissent: Unionism, the Encompassing Group and Territory}

Territory is a major component of cultural politics. An encompassing group will, very often, identify a territory over which it has a special claim. The relationship between the group and the land is not posed as arbitrary. Territorial integrity is wrapped up in the 
national story. Whether the nation is historically civil or ethnic, as is the case, respectively, with France and Ireland, territorial integrity very easily presents us with the opportunity, as Daniel Philpott put it, to "invoke the nineteenth century German romantic view that borders are "natural," destined by God or nature to circumscribe their inhabitants organically and permanently'. ${ }^{13}$

In Ireland, the integrity of the island itself has been central to the nationalism project. As Mary Daly said, 'the belief that the Irish nation included all inhabitants of the island was a central tenet of Irish nationalism both before and after 1922 [when Ireland became an independent state]. ${ }^{14}$ Until 1998, when it was changed in the wake of the Good Friday Agreement, the Irish Constitution stated that 'The national territory consists of the whole island of Ireland, its islands and the territorial seas. ${ }^{15}$

However, a million people in the north-east corner of the island were actively hostile to nationalist demands. The Unionist population was concerned to maintain their dominant position in Ireland and, in the years before the First World War, had moved militarily to circumvent Home Rule. From the perspective of the nationalists, moreover, the Unionists were a function of British power rather than an alternative nationalism. The 1916 Proclamation of the Republic stated that the Republic would cherish 'all the children of the nation equally, and oblivious of the differences carefully fostered by an alien government, which have divided a minority from the majority in the past. ${ }^{16}$ The Unionists - arising from the "differences carefully fostered' - were no more than an artificiality, an aberration caused by English interference in Ireland's affairs. Supporters of the nationalist project could not entertain the idea that a group within the island

${ }^{13}$ Daniel Philpott, 'In Defense of Self-Determination', Ethics, 105: 2 (1995), p. 368.

14 Mary Daly, 'Irish Nationality and Citizenship since 1922', Irish Historical Studies, 32: 127 (2001), p. 377.

15 Bunreacht na hÉireann, article 2. In the wake of a June 1998 referendum and as part of the implementation of the Good Friday Agreement, this article, along with article 3, was substantially amended to read: 'It is the entitlement and birthright of every person born in the island of Ireland, which includes its islands and seas, to be part of the Irish Nation. That is also the entitlement of all persons otherwise qualified in accordance with law to be citizens of Ireland. Furthermore, the Irish nation cherishes its special affinity with people of Irish ancestry living abroad who share its cultural identity and heritage.'

${ }^{16}$ Proclamation of the Irish Republic, Easter 1916. 
was capable of different and independently developed political aspirations.

The nationalist claim was for the whole island, regardless of the internal minority that would be created. Moreover, the internal minority's solution was to create another entity - Northern Ireland - that would produce its own minority. Neither group could entertain compromise over the land. For the Irish nationalists, any admission that these outsiders had rights over the land, or over the political destiny of the nation, would directly contradict the reasoning behind the original claim. The identity claim was based on the idea of an ancient cultural distinction that made Irishness at odds with Britishness. A group who made a similar claim, except in the other direction, could hardly be entertained.

In contemporary Ireland, relationships between the encompassing groups and territory continue to cause trouble. For example, even the most moderate of Unionists refer to self-identifications that certainly look a lot like the sort of nationalist identity that developed among Ireland's larger encompassing group. In response to the sort of language used in the Irish constitution, pre-Good Friday Agreement, David Trimble, the leader of the Ulster Unionist Party, said that 'Northern Ireland is not an artificial entity: rather the artificiality is the idea that the geographical landmass called Ireland should equate with the Irish political nation. ${ }^{17}$ The key to this statement is not the rejection of the idea that the 'geographical landmass' should equate to the Irish Political Nation, but the implication that Northern Ireland is not an artificial entity. Trimble is telling us that the natural markers for territory correspond to some other supposedly natural pattern - perhaps the residence of members of the Unionist encompassing group.

The Comprehensive Conception of the Group: Europe

The Irish encompassing group has changed significantly in the last number of decades. Largely as a result of membership of the European Union, Ireland has experienced profound economic and social changes. This has created tensions within the nation. The

\footnotetext{
17 David Trimble, 'Reply to a Letter by Gerry Adams', Irish Times, 3 February 1998 (courtesy of http://cain.ulst.ac.uk).
} 
manner in which being Irish was defined in the years surrounding independence was bound to come into conflict with the reduction in sovereignty that came about through both the opening of the Irish economy to the European model and through the integration of Irish social structures into the wider European scene.

Independence was rooted in the idea that a culturally-based nation required sovereignty in order to have control over its own destiny. Entry into Common Market, together with the UK and Denmark in 1973, was largely founded on the idea that membership would enable Ireland to weaken or break its economic ties with Britain. In other words, the European project was, for Ireland, part of a continued effort to achieve total independence. Whatever the intentions of Irish political leaders, however, the repercussions for Irish society and the idea of being Irish have been enormous.

For those people who continue to hold onto the form of Irish identity I am interested in, European integration is not solely a problem because of reduced institutional independence. They are also concerned that any loss of sovereignty will lead to a loss of cultural homogeneity. In September 2000, an argument took place over this sort of thinking when Síle de Valera TD, then a junior minister (for arts, heritage, Gaeltacht and the islands) ${ }^{18}$ and the granddaughter of Éamonn de Valera, the major figure in twentieth-century Irish national politics, gave a speech in which she said that Ireland had a greater affinity with the United States than with Europe. Her speech was motivated by a number of factors, not least political advantage. However, the interplay of ideological and cultural concerns in her speech is very interesting. ${ }^{19}$

De Valera told her listeners that "we have found that directives and regulations agreed in Brussels can often seriously impinge on our identity, culture and traditions. Brussels, Birmingham, the Burren; the same European Union, different worlds.' De Valera links this feeling with the supposed risk that the Irish will forget 'our close and very important ties with the United States of America.' On one level,

18 Teachta Dáile - an Irish member of parliament. Gaeltacht - an Irish-speaking area.

19 Address by Minister Síle de Valera at Boston College, MA, 18 September 2000, at http://www.ireland.com/newspaper/special/2000/devaleraspeech/; On the political context of the speech see, Garret FitzGerald, 'Minister's Frustration is no Basis to Query EU', Irish Times, 30 September 2000; Proinsías De Rossa, 'Government Detached from European Ideas', Irish Times, 23 September 2000. 
as with British Euroscepticism, her concern is directed towards the institutional integration of the EU and not by general economic globalisation or by American economic power. However, the interplay of ideology and the identity claim is striking. As Rory O'Donnell points out, opponents of EMU also tend to be opponents of other European-style political and social movements and policies, such as those relating to social partnership in the labour market. ${ }^{20}$

This juxtaposition between the EU's social market system to the more liberal Anglo-American one is conflated with various cultural factors. Europe is posited as simply more foreign than America. The United States does not present a threat to conservatives because of crucial place in the Irish encompassing group. America is posited as the home of Irish emigrants and their descendants, people who are attached to the idea of a free sovereign Ireland in the same way that American Jews are supposed to be attached to a free sovereign Israel. Irish emigrants to the US provided the basis for the development of nineteenth-century Fenianism, provided the funding for the war of independence in the 1920s and now provide the inward investment that has largely been responsible for Ireland's recent economic boom. In other words, the association with America is an association with the other Ireland - with the Diaspora. As John Costello, Taoiseach of Ireland in 1948, said when introducing the second reading of the Republic of Ireland Bill, 'The Irish at home are only one section of a great race which has spread itself throughout the world, particularly in the great countries of North America and the Pacific. ${ }^{21}$ In other words, the Americans and the Irish are blood relations - rooted in the same past.

The idea of being Irish is difficult to sustain in the face of external social and economic pressures. The attempt I have described here is aimed at incorporating American influence as consistent with Irish cultural sovereignty and to express discomfort with European influence as a challenge to sovereignty. Whether or not this is the case, the idea reveals the tortuous lengths to which people must go to in order to sustain a traditional idea of being Irish.

${ }^{20}$ Rory O'Donnell, 'New Ireland in the New Europe', in Europe: The Irish Experience, Dublin, Institute of European Affairs, 2000, pp. 189-90.

${ }^{21}$ Dáil Éireann, The Republic of Ireland Bill, second stage, 24 November 1948, vol. 113, p. 393, quoted in Mary E. Daly, 'Irish Nationality and Citizenship since 1922', Irish Historical Studies, 32: 127 (May 2001), p. 377. 
The Comprehensive Conception of the Group: Religion and Public Morality

Article 44 of the Irish constitution, while acknowledging that 'the homage of public worship is due to Almighty God', also allows for normal liberal freedoms of organized religion and religious expression. Nevertheless, this article of the constitution, together with the preamble, was for some time taken to imply both that the people of Ireland are 'a religious people' and that the worship of God was integral to public life. ${ }^{22}$ This interpretation was employed to maintain the legal ban on homosexuality when a test case was brought before the Irish Supreme Court in 1983. Norris was seeking to have an 1885 law declared unconstitutional, on the grounds that it interfered with a basket of rights ${ }^{23}$ that implied a right to privacy ${ }^{24}$ and contravened the preamble's proclamation that the constitution promote the 'due observance of prudence, justice and charity, so that the dignity and freedom of the individual may be assured. ${ }^{25}$ While the right to privacy was acknowledged, the argument of the plaintiff, Senator David Norris, was rejected 'on the ground of the Christian nature of our State and on the grounds that the deliberate practice of homosexuality is morally wrong, that it is damaging to the health both of individuals and the public and, finally, that it is potentially harmful to the institution of marriage.' Chief Justice O'Higgins concluded that there is 'no inconsistency with the Constitution in the laws which make such conduct criminal. ${ }^{26}$ The court rejected Norris's case 3-2.

The religious content of the constitution and its preamble reflected the Irish identity-claim. It is no accident that, when the constitution equates national citizenship with ideas of religiosity, it runs the risk of rejecting diversity. This description of the Irish people as a homogenous encompassing group reflects the ideology of the

${ }^{22}$ Quinn's Supermarket Ltd. v. A. G. [1972] IR, 1, 23. In Quinn's Supermarket Ltd. v. A. G., the benefits of worship are not restricted to Catholics, though the justices concerned saw no conflict with the acknowledged special position of the Catholic Church in the constitution. See James Casey, Constitutional Law in Ireland, London, Sweet and Maxwell, 1982, pp. 556-7.

${ }^{23}$ Bunreacht na hÉireann, article 40, §1, 3, 6.

${ }^{24}$ See McGee v. A. G. [1974] I.R. 284.

${ }^{25}$ Bunreacht na hÉireann, preamble.

${ }^{26}$ Norris v. A. G. [1983] IESC 1; [1984] IR 36 (22 April 1983). 
writers of the constitution. ${ }^{27}$ The writing of the constitution was conservatism in action.

Of course, the judgment was marginal, with two justices arguing from positions grounded in concepts of toleration. Indeed, the Norris case probably represented a turning-point in Irish constitutional history. In the last few years the constitution has become a battleground between those who wish to maintain a more conservative idea of being Irish and those - like Norris - who seek reform. A number of liberalizing referendums were passed through the 1990s as the power of the Catholic Church diminished. The Norris case itself was brought to the European Court of Human Rights (ECHR) in 1988, and the state was found to be in breach of Norris's rights. According to the ECHR, 'whilst national authorities... do enjoy a wide margin of appreciation in matters of morals, this is not unlimited'. ${ }^{28}$

Eventually, in June 1993, legislation banning homosexuality was revoked with 'barely a ripple of controversy. ${ }^{29}$ Nevertheless, during the Dáil Éireann debate, deputies from the main opposition argued that the repealing the 1885 legislation was both detrimental to public health and contrary to the moral duties of the legislature. One deputy - Gay Mitchell - complained that "it is Europe that is making us address this question here this evening; it is not the Department of Justice, the Government or this House. We are being compelled to address this question. That is regrettable in itself. We should make our laws as we see fit and not have to be dragged into making these laws by external bodies.' ${ }^{30}$

Political positions were not just being challenged from within but from Europe as well. While such debates are not inconceivable in other European states, it is notable that the liberalization of Irish society can be seen as bringing into question the very idea of what it is to be Irish. Throughout the 1990s, the implications of modernization, including membership of the European Union, caught up

27 Norris v. A. G. [1983] IESC 1; [1984] IR 36 (22 April 1983).

28 Case of Norris v. Ireland [1989] ECHR 6/1987/129/180.

${ }^{29}$ Tim Coone, 'Survey of Ireland (3): A few wobbles have not upset the tandem The Fianna Fail-Labour coalition is approaching the June Euro-elections in a confident mood', Financial Times, 25 May 1994; See for example, Dáil Éireann, 'Private Members' Business', Criminal Law (Sexual Offences) Bill, 1993, second stage, vol. 432, 23 June 1993.

30 Ibid. 
with Irish society. A sequence of corruption scandals rocked the political establishment, highlighting a change in the relationship between the political and social establishments and the citizenry. These, and other scandals, especailly over the contamination of blood producets, made manifest the tensions in the society between communitarian conceptions of the state-citizenry relationship and a more recent liberal disposition towards Irish politics. ${ }^{31}$ In themselves, the scandals emphasized the degree to which the previous conception of being Irish was unworkable.

In each of these subsections, I have provided an example of the negative consequences that the idea of being Irish had for political action. The conservative consequences of imagining the homogenous group were tangible. That is not to say that Irish independence was necessarily a mistake. It may be that there was a justice-based argument for independence. Perhaps because of the contemporary idea of being British or being English, the United Kingdom could not be administered justly. However, taking a cultural identity as a starting point was bound to lead to problems. The individual's position had to compete with that of the group and alternative groups were disadvantaged. This is as true of Northern Ireland's Unionists as of Irish nationalists.

\section{CONCLUSION}

Though the three examples given above are different in a number of ways, they do reflect the influence that cultural demands can have on political action. If a group has a conception of internal homogeneity or a direct link to territory, giving way to its demands cannot be seen as a cost-free exercise. Some degree of scepticism should be exercised before action is taken. Though there may be grounds for acknowledging and responding to cultural demands, such considerations must be seen in the light of the impact of policies on individuals.

There are two underlying and related points in this article. They are that the idea of being Irish is artificial and that the consequences

\footnotetext{
31 See Anne-Maree Farrell, 'Contaminated Blood and Political Scandal in Ireland', in John Garrard and James Newell, Scandals in Past and Contemporary Politics, Manchester, Manchester University Press, forthcoming.
} 
of seeking independence on cultural grounds were negative. Of course, all identity is artifice to some extent or other. Problems arise, however, when identities are used to lever autonomy for encompassing groups. The burden should lie with the encompassing group to prove that the rights and capacities of individuals caught within it will not be secondary to the group's drive for homogeneity. For those people and groups who are trapped by circumstance (and, in Northern Ireland, by their own homogenizing agenda), identity politics can cause profound harm.

In recent years, Ireland has shifted from being a net exporter of people to being a country of net immigration. Whether and how Irish identity adjusts to the fact of increased pluralism remains to be seen. There has been some hostility towards immigrants, and reports of racist incidents are widespread. However, this may be temporary. It may be, as Declan Kiberd suggests, a temporary response to sudden and traumatic social changes. ${ }^{32}$ Alternatively, hostility towards immigrants may simply be a reflection of narrowness and intolerance in Irish society. Either way, the days of cultural homogeneity are over.

In the wake of independence, the Irish state was founded on an idea of cultural homogeneity that competed with the needs of citizens. It may be, as I said, that there was a justice-based case to be made for Irish independence. However, taking the route of culture was a mistake. A state that seeks to represent and protect an identity, rather than to represent and protect individuals, will end up trading individual liberties and needs in exchange for an ideal.

${ }^{32}$ Declan Kiberd, 'Strangers in their Own Country: Multi-Culturalism in Ireland' in Edna Longley and Declan Kiberd, Multi-Culturalism: The View from the Two Irelands, Cork, Cork University Press, 2001, p. 50. 